\title{
INTEGRATED APPROACH TO MORAL EDUCATION
}

${ }^{1}$ Masuda Kamildjanovna Khashimova, ${ }^{2}$ Durdona Asilovna Mustafoeva, ${ }^{3}$ Malokhat Olimovna

Kamilova, ${ }^{4}$ Alisher Nasrullaevich Saydullaev, ${ }^{5}$ Ikromjon Ganijonovich Mamazhanov

${ }^{1}$ Associate Professor of the of the Tashkent Institute of Engineers of Irrigation and Agricultural Mechanization, Tashkent,

Uzbekistan.

E-mail: xmk_59@mail.ru.

${ }^{2}$ Associate Professor of the of the Tashkent Institute of Engineers of Irrigation and Agricultural Mechanization, Tashkent,

Uzbekistan.

${ }^{3}$ Senior lecturer of the Tashkent Medical Academy, Tashkent, Uzbekistan.

${ }^{4}$ Senior lecturer of the Tashkent Medical Academy, Uzbekistan

${ }^{5}$ Senior teacher of Andijan Agricultural and Agrotechnological Institute, Tashkent, Uzbekistan.

\section{ABSTRACT:}

In article process of moral education, his importance in the modern world is considered, it is analyzed questions of deepening and enrichment of content of moral education, formation of new approaches to moral education on the basis of integration of knowledge of such spheres as the biosphere, a noosphere and also moral education is treated both social, and personal needs.

Keywords: morality, moral perfection, moral culture, conscience, moral tradition, moral behavior, moral senses, moral conscientiousness, biosphere, noosphere.

Article Received: 18 October 2020, Revised: 3 November 2020, Accepted: 24 December 2020

\section{Introduction}

Moral education - a spirituality basis, and spirituality is a basis of any state. The basis has to be strong, otherwise, it can cause a crisis situation. Evolutionary development of society demands the constant growth of moral culture. Besides, intensive development of science, radical changes in society demand from the person of new outlook, new thinking, new approaches and the relations, high morality today. Evolutionary development of society first demands constant perfection of moral spiritual culture. Secondly, modern intensive development of science and technology also demands from mankind of new outlook, new thinking, the new relations and high morality. In the third, moral education which is a spirituality basis demands to lift the basic changes happening in society to higher level. In the pedagogical encyclopedia, moral education is defined as the purposeful formation of moral consciousness, the development of moral feelings, the development of skills and habits of moral behavior. The definition shows that morality as a personal characteristic is a very complex phenomenon that unites such personal structures as reason, feelings, will. Therefore, moral education is defined as a single process of education: - moral feelings (conscience, duty, faith, responsibility, citizenship, patriotism), moral character (patience, mercy), - moral position (the ability to distinguish between good and evil, the manifestation of selfless love, readiness to overcome life trials), - moral behavior (readiness serving the people of the Fatherland, manifesting spiritual prudence, goodwill). From the definition of the Pedagogical Encyclopedia given above, it becomes clear that morality can only be considered as a complex, multi-level system, combining such qualities as reason, will, feelings. The creation of a stable system of moral beliefs, thanks to which a person can independently understand the border between moral and immoral, is determined by the unity and harmony of moral consciousness, expressed in stable moral habits. This belief system tells us about a person's moral maturity. This is an 
important sign of the correspondence between the process of education and the development of morality in the educated.

We have deeply studied process of moral education, have carried out the careful analysis of the current situation, have established the available shortcomings and their reasons. Now the pedagogical science considers questions of morality as social requirement. And the concept forms a basis at the organization of moral education. During process of moral education the main attention is paid to external elements of education, i.e. education of moral behavior and the culture of communication. However, on education of moral consciousness, on formation of moral senses and moral beliefs we approach superficially. Moral education which isn't supported with sensibleness and feelings can't be full and doesn't meet the modern requirements.

Now we in the course of moral education use the following methods: schooling, explanation, personal example, training, encouragement, punishment. These educational methods are effective in education of culture of communication, moral behavior with participation of the teacher-tutor. But, the methods above specified are insufficiently effective for formation of moral consciousness and moral beliefs especially in the course of self-education.

\section{Materials and methods}

Education of moral consciousness is based first of all on thinking of the personality, but we in the course of moral education almost don't use method of the scientific analysis. And also we don't study such question as - morality in thinking. Meanwhile it is necessary to emphasize that education of moral consciousness has to be based on moral thinking. We won't think and we don't reflect that not respect for standards of morality can join, eventually, negative physiological changes. We treat questions of morality, only as the social requirement and we study this question in a narrow foreshortening. And it leads to unilateral and narrow approach in moral education. The possibility of achievement of obviously planned purposes in process of moral education is as a result lost.

Today the mankind enters the new sphere which is designated as a noosphere. The noosphere declares itself as the transformed biosphere, her new qualitative state. About this new qualitative state V.I. Vernadsky left the reflections in incomplete work "A scientific thought as the planetary phenomenon". The main idea of this work is in justification of a thesis that a noosphere not a utopia, and the strategy of real survival of mankind, permission of global problems, in conditions when the mankind becomes "universal" category.

The subsequent development of society has shown that the noosphere is not only means of solution of problems, but also a problem. The power of reason can be transformed for the good, and can turn back the evil. The person is a special component of the biosphere, her conceiving reed" One of the weakest creations of the nature, people becomes the "miracle" capable by force of thought to embrace all Universe. The reason of the person changes the planet, and a conclusion arises here, that geological force is not Homo Sapiens, but his mind, a scientific thought of all mankind. From here it is possible to draw a conclusion that today the mankind has to learn to think on moral canons, respecting ethical standards.

Today, as a result of rapid development of human mind, versatile influence of a noosphere, especially negative influence on other spheres has sharply increased. It is resulted by global problems. In due time V.I. Vernadsky noted: "Evolutionary development mankind will rise by such step when the noosphere will get huge force and it will lead to emergence of global problems for mankind. Only integration it is separate the developing sciences, can give an opportunity of solutions of the arisen global problems". Because integration expands a round of researches and gives the chance to an integrated approach. Proceeding from these logical reasons, it is expedient to organize scientific research works by 
integration of sciences. Synthesizing and creation of uniform conclusions of discoveries of related sciences is sources of solutions of new problems or emergence of the new directions. Proceeding, for these reasons we in the scientific research at the solution of problems of moral education have addressed integration of sciences and collection of information to synthesis and development of the uniform conclusions in the field of biology, biophysics, bioenergetics, the biosphere, medicine, noospheres connected with morality.

\section{Result and discussion}

Today, we have to pay special attention to deepening of processes of moral education, contents enrichment, development of moral spiritual consciousness and moral senses, formation of new approaches to moral education on the basis of integration of knowledge of such spheres as the biosphere, a noosphere, biology, physiology, psychology, bio-energetics. Such approach to the solution of questions of moral education is considered expedient, it gives the chance to enrich the content of moral education, to understand need and the importance of moral education, to realize that the morality comes to the arena not only as social, but also personal need in the course of survival of the society and each person who is separately taken now. Such complete approach to increase efficiency of moral education and will serve as motive to independent work of an individual on itself.

By disclosure of influence of morality on the biosphere and on biological essence of the certain person we will be able to awaken new motives and personal interests in students. Such approach will open new opportunities in the course of moral education, will expand an outlook circle, will enrich the content of moral education, forms new motives and will increase efficiency of this process. Because, the doctrine which has personified not only social, but also personal interests, can be full and perfect and also have enormous educational influence.

\section{Conclusion}

By revealing the influence of morality on the biological essence, on the health of an individual, we will be able to awaken new motives and personal interests in future specialists. The study of moral canons based on physiology, bioenergetics and human psychology will open up new opportunities in the process of moral education, expand the range of worldview, enrich the content of moral education and increase the effectiveness of this process. Having introduced the specificity of the question, we studied the process and the significance of moral education under the angle of biological and physiological laws. Studied how moral feelings such as respect, love, joy, gratitude, honor affect human health. The influence of negative feelings on human health was compared. For example, any virus is a low-vibration organism with a closed structure of an electromagnetic circuit with a resonance frequency of approximately 5.5 and 14.5 hertz. Starting from 25.5 hertz, the virus dies. We know that emotions also appear as vibrations and it is measured in hertz. Negative emotions manifest as vibrations:

- grief - from 0.1 to $2 \mathrm{~Hz}$;

- fear - from 0.2 to $2.2 \mathrm{~Hz}$;

- resentment - from 0.6 to $3.3 \mathrm{~Hz}$;

- irritation - from 0.9 to $3.8 \mathrm{~Hz}$;

- disturbance - from 0.6 to $1.9 \mathrm{~Hz}$;

This means the above feelings create favorable fluctuations for the development of the virus.

High vibrations are manifested with the following feelings:

- generosity - $95 \mathrm{~Hz}$;

- gratitude - $45 \mathrm{~Hz}$;

- heartfelt gratitude - from $140 \mathrm{~Hz}$ and above;

- love and friendliness - $154 \mathrm{~Hz}$ and higher;

- complicity and compassion - from $150 \mathrm{~Hz}$ and above;

- unconditional love - from $205 \mathrm{~Hz}$ and above.

Such examples show how important it is to cultivate moral feelings in oneself. The study of the importance of moral upbringing using the 
latest discoveries in the field of bioenergy and biophysics reveals great opportunities in the formation of personal motives that push the students to moral improvement. This approach yielded results. If we compare the traditional approach, which is mainly based on social requirements, and the integrative approach, which is aimed at awakening personal interests, then you can see that academic performance has increased from 62 percent to 72 percent. With an

\section{traditional approach}

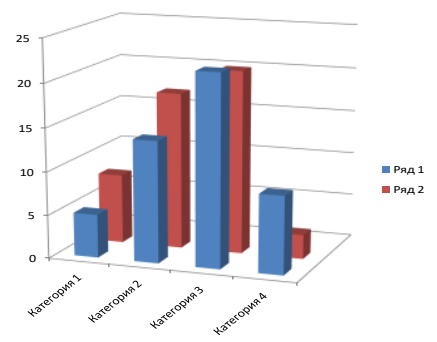

\section{References}

[1] Вернадский В.И. Научная мысль как планетное явление. М., Наука,1991.

[2] М.К.Хашимова. Биоэнергетик қонуниятларни ўрганиш асосида ахлоқан ривожлантириш. «Педагогик таълим» журнали 2001йил. № 3. 19-21 lists.

[3] Вульфсон Б.Л. Нравственные императивы и задачи воспитания. “Педагогика",№ 1. 2006.C 8-11 lists.

[4] Masuda K. Khoshimova. The Problems of Bringing up the Moral Perfect Personality . Издагельство Аипч Kommunikat ions und Verlagsgesel 1 s chaft $\mathrm{mbH}$. Konigsallee $68,4 \quad 0 \quad 212$ Diisseldorf 2018.

[5] М.К.Хашимова.

Нравственное воспитание - основа духовности. Журнал «Вопросы гуманитарных наук».- М.:2008. - № 6. С. 33-36 lists.

[6] М.К.Хашимова. Проблемы нравственного воспитания. Журнал integrated approach, perception and understanding of the essence of moral education expanded the horizons of knowledge, this is in its turn strengthened moral consciousness, moral convictions and served as the basis for the formation of moral principles among future medical workers. Because the teaching, which embodied not only social, but also personal interests, the integration of knowledge has a colossal educational impact and high results.

\section{integration approach}

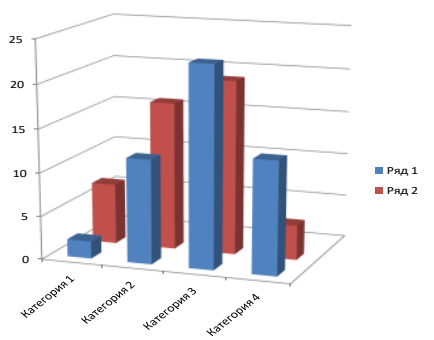

«Вопросы гуманитарных наук».M.:2009. - № 2. C. 207-300 lists.

[7] М.К.Хашимова. Баркамол авлод келажагимиз пойдевори. Ж. «Антик Дунё» -ANTIQUE WORLD.: 2010 №1- 2. - Б. 34-35 lists.

[8] Бразговка Л.П. Значение нравственной установки в процессе морального становления младшего подростка / Бразговка Л.П. // Этическое воспитание. - 2007. - N 3. - c.35-40

[9] Величко О.Ю. Методы стимулирования нравственного развития младших школьников / О.Ю. Величко // Начальная школа + практика: (вкладка к четным номерам). - 2010. - N 7. - с. 97100

[10] Величко О.Ю. Роль нравственноориентированной игры в процессе этического воспитания младших школьников / О.Ю. Величко // Начальная школа. - 2008. - N 8. - с.1115. 
[11] Masuda . Khoshimova. The use of modular technology in education.

[12] Journal of Critical Reviews. Accepted: 18.03.2020.

[13] Melibayeva R.N., Khashimova M.K., Narmetova Yu.K., Komilova M.O., Bekmirov T.R. Psychological Mechanisms Of Development Students' Creative Thinking. INTERNATIONAL JOURNAL OF SCIENTIFIC \& TECHNOLOGY RESEARCH VOLUME 9, ISSUE 03, MARCH 2020. 